\title{
Very High Purity Aluminum: An Historical Perspective
}

\author{
STEPHEN J. LINDSAY ${ }^{1,2}$ \\ 1.-Alcoa Primary Metals, Technology, Innovation \& Center of Excellence, Alcoa, TN 37701-2516, \\ USA. 2.—e-mail: stephen.lindsay@alcoa.com
}

\begin{abstract}
The origins of High purity aluminum production are likely to have a strong impact on future production in conventional reduction cells. Many of the key elements that are necessary to produce Very High purity ingot were in place at the very beginning of the 20th century. In this article, the author examines some of the history of the industry. He also comments on aspects of aluminum smelter design that will continue to serve purity markets into the 21 st century.
\end{abstract}

\section{INTRODUCTION}

The future of High purity aluminum production may end up being a continuation of applied research and development that began in our industry a century ago. Many of the work methods, systems, and subprocesses that have enabled the production of Very High purity ingot in aluminum reduction cells since the early 20 th century are now obsolete for the designs of new smelters. The remnants of these factors at legacy smelters will carry Very High purity forward, at least into the first quarter of the 21st century. But before going into detailed discussion on these evolutionary changes, let us revisit some definitions.

\section{DEFINITIONS}

The book, Aluminum Properties and Physical Metallurgy ${ }^{1}$ notes that, "There is no generally adopted nomenclature for the various degrees of purity of aluminum." The classification shown in the following table is appropriate.

\begin{tabular}{|c|c|}
\hline Aluminum, $\%$ & Designation \\
\hline $99.50-99.79$ & Commercial purity \\
\hline $99.80-99.949$ & High purity \\
\hline 99.950-99.9959 & Super purity \\
\hline $99.9960-99.9990$ & Extreme purity \\
\hline Over 99.9990 & Ultra purity \\
\hline
\end{tabular}

Furthermore, Very High purity remelt ingot includes grades classified by the Aluminum Association as P0202A, P0303A, and P0404A. ${ }^{2}$ The sum of acceptable metallic impurities in these grades places them in the upper end of the High purity classification that is shown above, between $99.88 \%$ and 99.949\% Al. Thus, the term, Very High purity ingot is appropriate and is consistent with the literature. In most cases, these metal grades approach the practical limits of purity from conventional aluminum reduction cells.

However, a few primary aluminum smelters can, and do, produce limited quantities of Super purity metal that is between $99.95 \%$ and $99.97+\% \mathrm{Al}^{3}$ In this reference from 2013, ingot of this quality is referred to as Ultra High purity metal. The citation reinforces the comment made above that we still are lacking a standardized general nomenclature for pure forms of ingot in our industry.

\section{THE BEGINNINGS OF HIGH PURITY ALUMINUM}

The designations for aluminum purity grades were not as important in October 1918, when these early photos ${ }^{4}$ of aluminum ingot from original Hall cells were taken (Fig. 1). But, that does not mean that purity was not important a century ago. The Pittsburgh Reduction Company had been pursuing the fledgling, electrical conductor cable market as early as $1899 .^{5}$ The renamed Aluminum Company of America began producing aluminum cable-steel reinforced (ACSR) in 1908 after it was invented by Dr. William Hoopes of the Alcoa Research Laboratories. Although a clear citation is lacking, it is presumed that in 1916 that "G"-grade (general purpose?) metal was not of high enough purity and conductivity for the head-to-head competition that was going on at that time with copper. Remember 

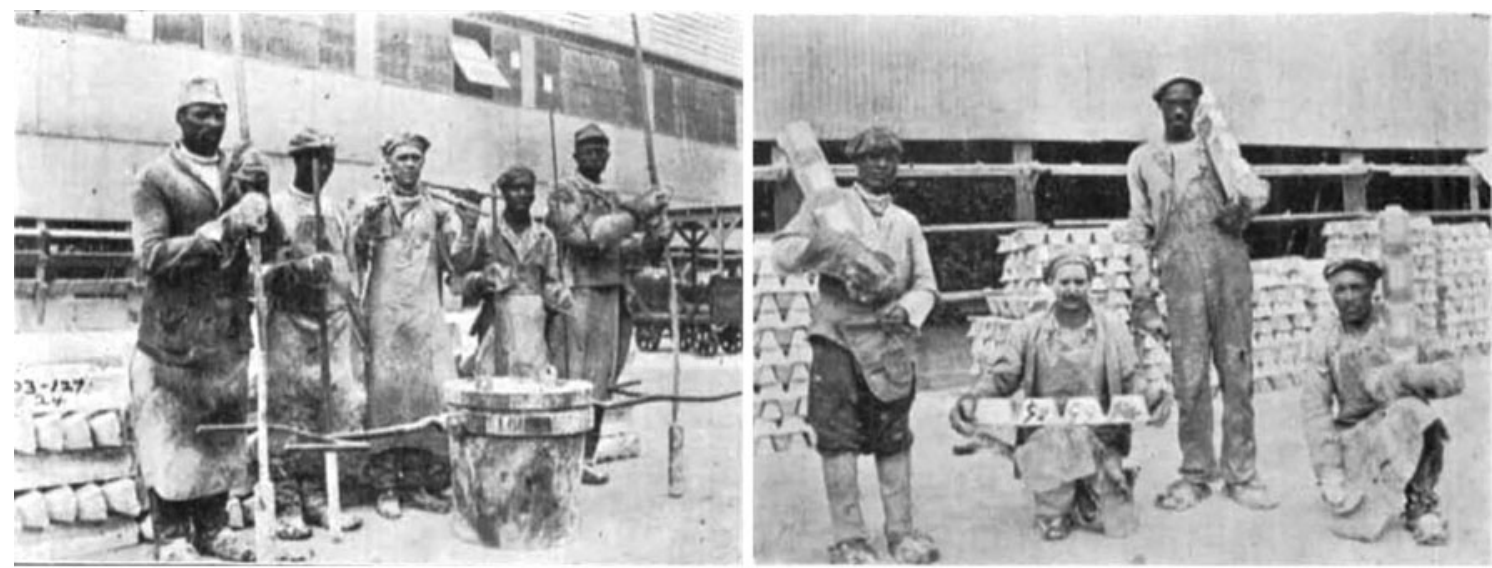

Aluminum Company of America, North Maryville, TN Reduction Plant, October 1918 - First cast of "A" grade aluminum. Pictured left to right: Tom Matthews, Sam Britton, Fountais Whittaker, Dave Johnson, Eugene Savell, Will Garrett, Dave Williams, Jim Webster and Sam Townsend. This crew $\mathbf{1} 1$ not pictured from Room1, Section 4 shared a prize of \$30 after two years of trying to produce " $A$ " grade ingot.

Fig. 1. Early focus of Alcoa on better than common, commercial grades of aluminum ingot (provided courtesy of Alcoa, Inc.).

that local electric utility grids were first being constructed in many communities. But then, as now, the ability to keep cable weights down by keeping impurity levels low was just as important. It was in that year, 1916, that the Tennessee Reduction plant began its pursuit of "A"-grade metal.

It was only a few years later, in early 1920 , when Dr. Hoopes, in collaboration with Dr. Francis Frary, ${ }^{6}$ would invent the Hoopes Alumina Refining Process ${ }^{7}$ that is illustrated in Fig. 2. It initially produced metal of $99.99 \%$ purity. ${ }^{\text {B }}$ By 1938 , aluminium of $99.996 \%$ purity had been produced in France using a modified Hoopes process. Thus, it is clear that commercial interest in High purity aluminum production from reduction cells and Super purity metal production using special refining processes has been a part of our industry for a very long time.

\section{ENABLERS TO HIGH PURITY}

We might think that technical advances over the past century have improved the capabilities of reduction cells to produce Very High purity ingot. It is true that there have been certain improvements with more modern cell designs and operations. There have also been improvements in understanding of mass balances for various impurities. ${ }^{8}$ However, many of the major enablers to the production of Very High purity ingot were there at the beginning, and a number of these key enablers have been slipping away as our industry has been modernized, especially since the late 1970 s.

There are some key factors to take note of in the early configuration of the pot line shown in Fig. 3 .

(1) The pots are fed with fresh (pure or unreacted) alumina applied manually.

(2) Exhaust fume and particulates are not returned to the pots by automated systems.

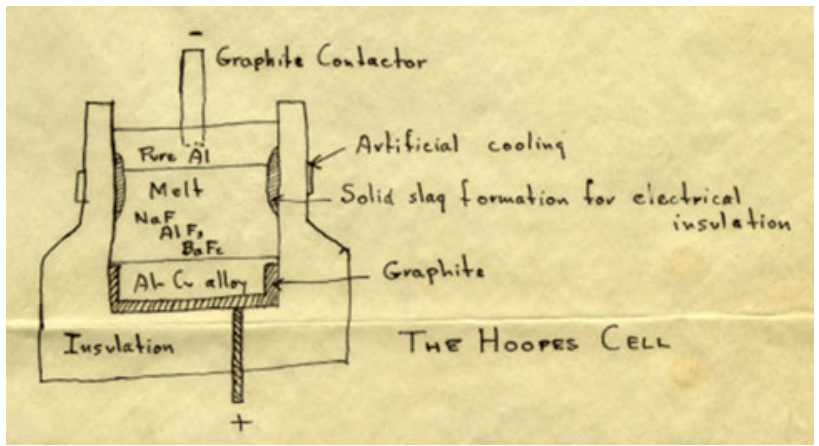

Fig. 2. The Hoopes aluminum refining process ${ }^{6}$ (provided courtesy of Alcoa, Inc.).

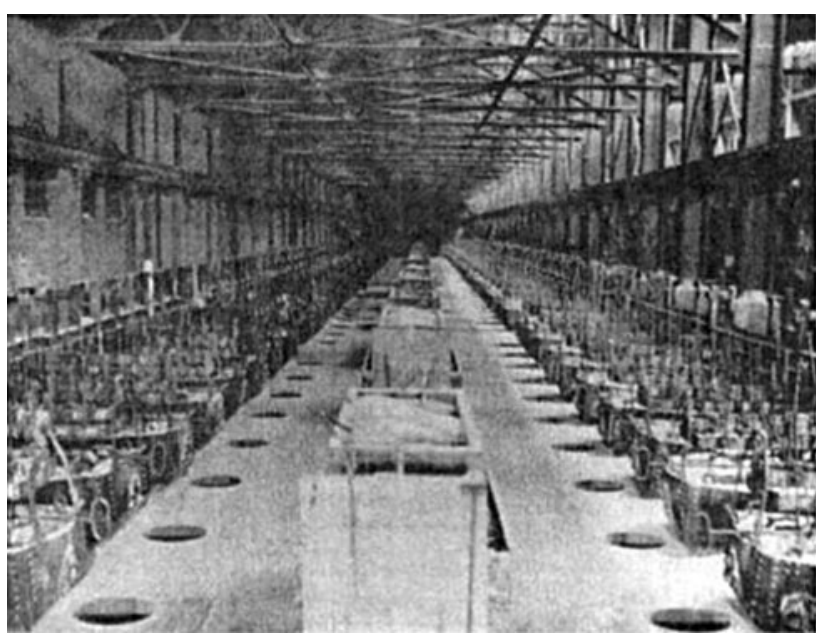

Fig. 3. The smelting pot room at Massena, NY, in $1914^{5}$ (provided courtesy of Alcoa, Inc.).

(3) Bath, or pot crust, additions were applied manually, enabling pure anode cover on some pots.

(4) Tapping was done in small batches into small crucibles set into "wells" at the end of each pot. 
(5) The cells themselves were small in size.

(6) Casting of "pigs" was done in small batches, with no intermediate vessels or furnaces.

(7) Individual cells could easily be designated for "special" work practices.

(8) Individual cells could easily be put on shorter anode change rotations.

These are not the only factors that have enabled the production of Very High purity metal. But as the ability to apply many of these principles have disappeared from modern aluminum smelter designs, the ability to produce and capture Very High purity ingot in quantity has become increasingly difficult.

Consider a modern cast shop. The production of foundry ingot, billet, rolling slab, and other products requires an accumulation of metal often more than $150000 \mathrm{lbs}$ in a holding furnace. If the pot rooms cannot produce sufficient quantities of Very High purity metal in sufficient time to align with casting schedules, then the "sweetest" metal from individual pots may no longer be captured as ingot. The capture of small and variable quantities of Very High purity production requires the ability to cast in small lot sizes. This usually requires more intense labor methods that are now generally avoided in modern cast shop designs.

The same is true for smaller points of accumulation in crucibles. These issues are overcome more easily. For example, selective tapping routines can be used to take a crucible of metal from two or three pots that may not be in close proximity. But this does not allow the High purity metal from all pots that meet the grade to be captured as ingot. Often, one pot that was on grade when last sampled is no longer so when tapped. Thus, it may spoil the pure metal from other pots that are tapped into the same crucible. Metal "heels" in the bottoms of crucibles may do the same, especially if the crucible has recently been used to tap pots of lesser purity. The bigger the crucible is, the greater the risk becomes.

Finally, the cells themselves were small. If one cell encountered a problem, then it would contaminate all of the metal in the pot. But the quantity of metal affected was minimal. Modern cells are quite large. Some even approach $20 \mathrm{~m}$ in length. Even though the impact of a fallen plunger tip or a burnoff may be spread over many more tons of metal in a cell, the impact can be enough to put all of that metal off grade. As it generally takes 3 weeks for a cell of almost any size to recover from a purity problem via dilution of the pool of metal in the cell, a large cell may have to produce more than 50 tons of aluminum before it can be back "on grade," which is not so for smaller cells. Refer to Fig. $4 .^{9}$

To this day, the older, smaller, reduction cells generally are dedicated to production of Very High purity metal. This is not to say that it is impossible for large, modern cells to produce such metal grades. But the ability to capture production units

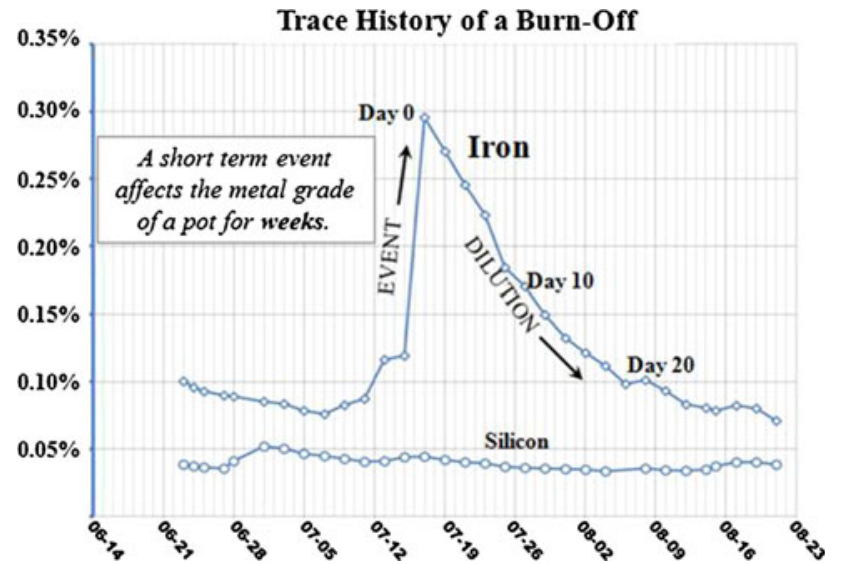

Fig. 4. Example of dilution of iron in the metal pad after a burn-off ${ }^{9}$ (provided courtesy of Alcoa, Inc.).

of High purity as ingot slips away as batch sizes increase.

This may sound like much ado about nothing. But at the time of this writing, at least one location was known to be producing 120000 lbs per day of High purity metal in the pots. It was not enough quantity for the furnaces and casting equipment to be able to capture it as a drop. Therefore, the opportunity to produce the product and realize the margin was lost to another provider. The ability to capture pure metal production in small batches is still important.

\section{MATERIALS}

We must also acknowledge "the changing palette of raw material quality"10 and its effect on Very High purity production. As raw materials such as coke and alumina with very low impurities of iron, silicon, and others become scarce and more expensive, the economics of being in the Very High purity remelt ingot business can weaken. For the highest purity forms, P0202A and better, the difference in production cost shrinks for ingot produced by conventional reduction cells versus metal from the Hoopes Process or from other secondary purification processes, such as fractional crystallization and zone refining. Thus, the future of Very High purity ingot is expected to continue to shift gradually toward aluminum that has been refined by such processes.

With this reference to raw materials and alumina, it is important to note that with rare exception it is no longer possible to find pot lines of modern design that have any practical way to feed individual cells or groups of pots with pure, unfluorinated alumina. A variety of innovations in alumina distribution systems have been made in recent decades. While these technologies are quite capable of transporting fresh alumina to the pots, doing so would require some construction of redundant systems to store and/or to transport a choice of fresh or fluorinated 
alumina. The additional capital expense would have to be satisfied by a business case built on years of High purity production, capture, and sales. This often presents a hurdle too high for greenfield and brownfield facilities to consider.

The days of filling alumina bins from portable buckets or from vehicles have also become a living memory at many older aluminum smelters. Refer to the photo in Fig. 5. Without systems to distribute pure alumina, the impurities that attach themselves to particulate matter in pot exhaust fume ${ }^{11}$ find their way back into the metal produced by all pots. However, the "obsolete" way of transporting alumina to pots does have extensive flexibility to be able to designate certain cells, or groups of cells, for pure alumina feeding. It also allows the efforts to produce certain amounts of High purity metal to be tailored to a business opportunity of moderate scale simply by adding or subtracting the number of pots that are put on a strict regimen of pure alumina feeding. This flexibility also helps to keep added costs of purity production to a minimum by not having to apply special measures to many pots in order to gain exceptional levels of purity for product that serves a niche market.

\section{EVOLUTIONARY CHANGES}

Changes in alumina distribution system designs are not the only element of evolutionary changes. In the days of portable, crane-mounted buckets for anode-covering material, it was often possible to place "regular" anode cover on most pots and "pure" anode cover on some pots. Some locations making Super purity ingot also cover anodes only by using pure alumina. ${ }^{3,10}$

Like the recycle loop for impurities that exists with particles and fume from pots to fluorinated alumina, anode-covering material provides another large avenue for impurities to leave and then return to pots. Having the ability to select which pots receive various compositions of anode-covering mate-

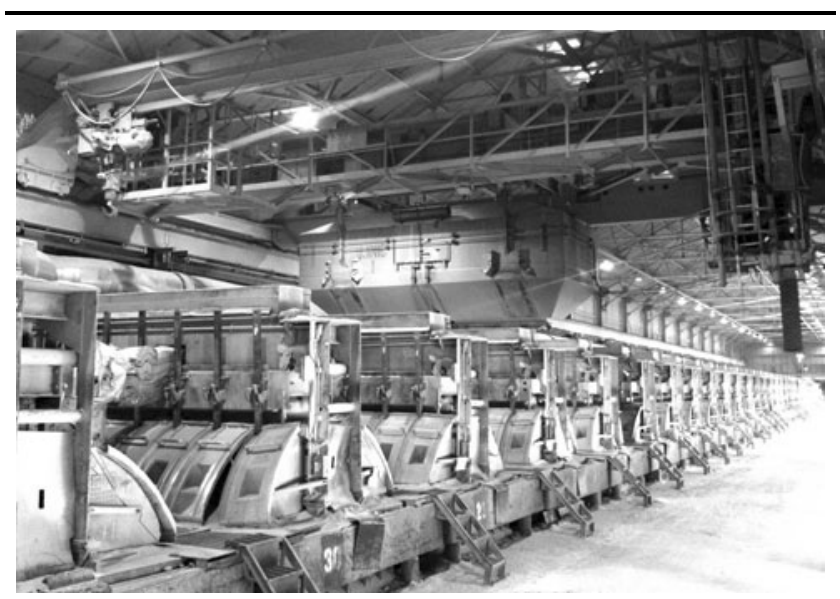

Fig. 5. Filling of alumina bins on pots from a crane-mounted bucket (provided courtesy of Alcoa, Inc.). rial has also become obsolete, or it is only a living memory in older technology smelters that remain in operation.

Modern systems often use air-swept autogenous mills and pneumatic conveying systems to multiple points that fill covering material bins on pot tending machines. While these systems are fast, are efficient, and require a minimum of manpower, they also spread impurities far and wide. When put in combination with modern alumina distribution systems that have no redundant or parallel system for pure alumina delivery, it becomes a rarity for smelters to produce any of the Very High purity grades.

Some exceptional pot lines do produce a fraction of their output as P0404A grade ingot. Even with excellent raw materials, work practices, and anode quality, the production of higher purity grades in substantial quantities remains all but impossible.

There have also been evolutionary changes in systems to capture and control fumes over the past six decades. In 1889, Charles Martin Hall referred to the Pittsburgh Reduction Company's first smelter as "Satan's Church," where it took a good "deal of ability as well as grit to stand ... the dirt, soot and worse, the fumes..."

The first systems used to treat these fumes from pot lines were wet scrubbers. Often, these were built in combination with settling chambers, or drop-out boxes, to recover some of the value of bath, fluoride, and alumina that were carried away with cell exhaust. But the finer fractions, those that carried the heaviest burden of impurities, ${ }^{11}$ usually ended up being disposed of as wet sludge. Even though these systems did not produce environmental results that can compare with modern dry scrubbers, a few environmentally "grandfathered" locations can still be found in operation today. These legacy scrubbers provide an important sink for impurities such as iron, enabling production of High purity metal. Thus, the few remaining locations with wet scrubbing systems and at least one location with no scrubbing system at all can, and do, produce Very High purity ingot.

Once dry scrubbing systems became common in the industry, it was not the end of an era for Very High purity production. All cells needed to be connected to the dry scrubbers to recover the fluorides and to control emission losses. But not all cells needed to be fed with fluorinated alumina. Alumina recirculation could simply be used to move the impurity losses to fumes from pots fed with pure alumina to other pots that consumed fluorinated alumina. The available surface area on the alumina was generally sufficient to run up to $33 \%$ of all cells using pure alumina feed and purity-driven work practices before a substantial increase in fluoride emission losses were realized.

As most pot lines have crept line load upward to remain competitive this advantage has also been progressively sacrificed. In many cases the factors 
that have pushed for greater production from the same reduction cell footprints have also driven up the rate of total fluoride evolution from the cells to the dry scrubbers. At its ultimate conclusion all fresh alumina that enters a smelter must be passed through the dry scrubbing systems to meet the higher load of fluoride coming off the cells leaving almost no opportunity for groups of cells to be fed with pure alumina in a number of cases. ${ }^{12}$

A small number of smelters have been built with fluid-bed-type dry scrubbing systems. These locations do have some advantage over locations that have the more typical injection-type dry scrubbing systems for fume control. The fluid-bed systems can process a high loading of fluoride without strong negative impacts on emissions. This additional contact and residence time of the fluid-bed scrubbers also can permit a larger percentage of pots to be put on pure alumina feed. The same applies to pot lines that are operating at higher line loads and elevated total fluoride evolution rates. At least three locations in the world have used this type of fume control system to create advantage by production of Very High purity metal. However, the capital and operating costs required to build such systems for new pot lines have proven to be prohibitive.

\section{WORK PRACTICES AND ANODE CHANGING CYCLE}

What is often left for pot lines of the most modern designs are the last two factors listed above: placing some cells on special work practice routines and varying the duration of the anode changing cycle.

To be sure, these are both important factors in being able to produce Very High purity ingot. But are they enough in and of themselves? The answer seems to be, "Yes, but rarely."

Figure 6 illustrates the power of altering the anode changing cycle. As the anode setting cycle is reduced, the thickness of anode butts will increase in a predicable fashion. This approach is often used to boost the production rate of certain grades of High purity or Very High purity ingot at smelters. But it comes at a cost. Thicker anode butts must be crushed and reprocessed. More anode assemblies must be consumed over time, adding labor, energy, and other costs. Ultimately, the application of this approach must pay for itself via access to premiums on metal units that are sold as premium product. It is not necessarily a cost-prohibitive approach, but it can quickly eat into the margins that are realized on the sales of pure forms of ingot.

The other approach is to apply special attention to work standards either in the pot rooms, or across the operations, to achieve a "Purity Mindset' in all employees on site." ${ }^{3}$ This, too, can enable production of Very High purity ingot when used in combination with anode-changing cycle control and strict controls on bath levels and dozens of other, lesser factors. However, without access to enablers to pure

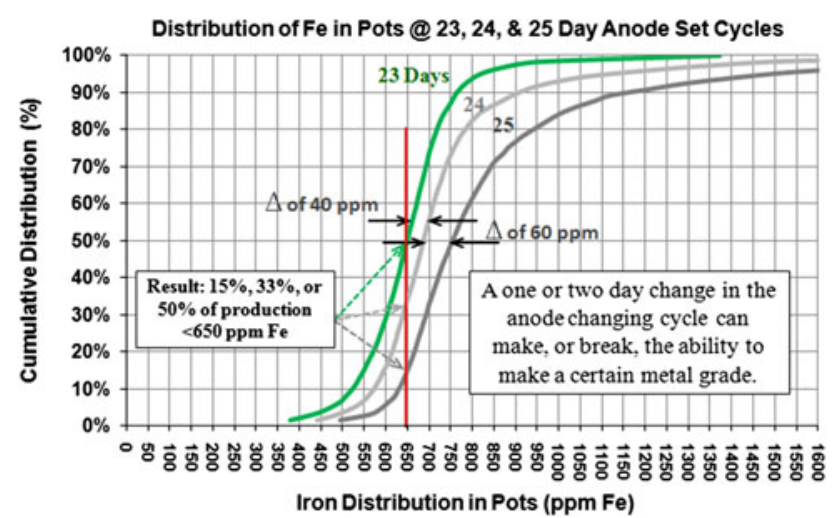

Fig. 6. Effect of anode changing cycle on yield of $<650 \mathrm{ppm} \mathrm{Fe}$ in aluminum $^{9}$ (provided courtesy of Alcoa, Inc.).

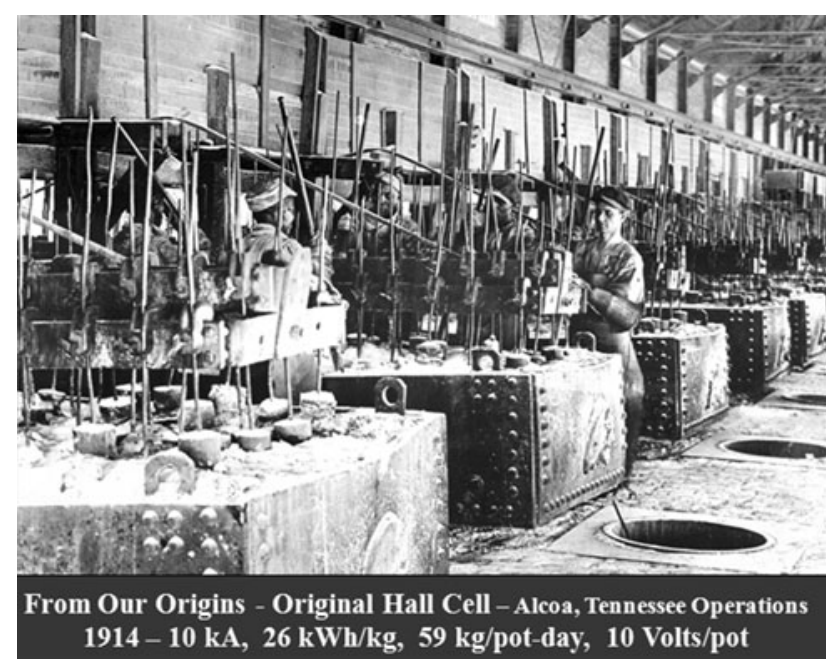

Fig. 7. Tennessee Operations of Alcoa celebrated its 100th year of operation in 2013, the same year that Alcoa, Inc. celebrated its 125th anniversary (provided courtesy of Alcoa, Inc.).

alumina feed and pure anode cover, it is generally not possible to produce Very High purity ingot of better than P0404A grade in large quantities.

\section{CONCLUSIONS}

We have seen that even in the early days of the aluminum industry that then, as now, there was a need for metal of high purity and a focus on its production. While many systems and techniques have improved over the past century, many of the fundamental enablers to the production of Very High purity grades were in place at the very beginning.

As the decades have passed, the designs of new smelters have changed to become more automated and more cost effective. The capital costs and operating costs associated with pursuit of High purity and Very High purity grades are often too high of an entry fee compared to options to pursue other value-added products that are not as demanding on metal purity. 
This evolution has placed some legacy pot lines and smelters in a unique situation. They are more likely to be able to remain competitive for a longer period of time by being able to produce metal grades that large, modern pot lines cannot. With the exception of some metal purification by secondary processing, the bulk of P0202A to P0404A ingot grades falls into this niche. A few smelting locations can also produce significant quantities of better than $\mathrm{P} 0202 \mathrm{~A}$ grade ingot from older technology cells.

By taking advantage of older technology, applying some key countermeasures, and fostering of a "purity mindset," it is quite likely that some cells from the middle of the 20th century will carry Very High purity ingot production well into the 21st century before a complete transition to secondary aluminum refining processes eventually comes to dominate certain sectors of the Very High purity market.

\section{ACKNOWLEDGEMENTS}

The author would like to acknowledge Alcoa, Inc. (Fig. 7) for support in the preparation and publication of this article and Dr. Margarita R. Merino (Ph.D., Florida State University) for her encouragement, dedication, and support.

\section{REFERENCES}

1. J.L. Brandt, W.B. Frank, G.P. Koch, J.J. Mills, and J.E. Hatch, eds., Aluminum Properties and Physical Metallurgy (Materials Park: American Society for Metals, 1984), p. 1 .

2. The Aluminum Association, International Designations and Chemical Composition Limits for Unalloyed Aluminum-North American and International Registration Record (Arlington, VA: The Aluminum Association, 2007), p. 2.

3. S. Hamilton and R. Cook, Light Metals, ed. Barry Sadler (Warrendale, PA: TMS, 2013), p. 27.

4. Aluminum Bulletin, 1 (1) (North Maryville, TN, 1918).

5. G.D. Smith, From Monopoly to Competition-The Transformations of Alcoa, 1888-1986 (Cambridge, UK: Cambridge University Press, 1988), pp. 26, 88-90, 102.

6. P.L. Patterson, The Hoopes Aluminum Refining Process, notarized letter, 17 May 1933, http://digitalcase.case.edu: 9000/fedora/get/ksl:spcbru01084/spcbru01084.pdf.

7. F.G. Frary, J. Am. Electrochem. Soc. 47, 275 (1925).

8. W. Zhang, X. Liu, P. McMaster, and M. Taylor, Light Metals, ed. W. Hale (Warrendale, PA: TMS, 1996), p. 405.

9. S.J. Lindsay, Measures to Control Metal Purity in Pre-bake Reduction Cells, TMS Industrial Electrolysis Course Notes (Warrendale, PA: TMS, 2013).

10. S.J. Lindsay, Light Metals, ed. Barry Sadler (Warrendale, PA: TMS, 2013), p. 925.

11. H. Gærtner, A.P. Ratvik, and T.A. Aarhaug, Light Metals, ed. C.E. Suarez (Warrendale, PA: TMS, 2012), p. 839.

12. S.J. Lindsay and N.R. Dando, Light Metals, ed. Geoff Bearne (Warrendale, PA: TMS, 2009), p. 275. 